\title{
Isolation, detection of virulence genes, antibiotic resistance genes, plasmid profile, and molecular typing among Vibrio parahaemolyticus isolated in Malaysian seawater from recreational beaches and fish
}

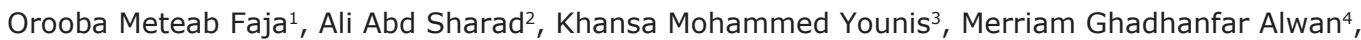 \\ Basima Jasim Mohammed ${ }^{1}$ and Asmat Ahmad ${ }^{4}$
}

1. Department of Public Health, College of Veterinary Medicine, University of Al-Qadisiyah, Iraq; 2. Department of Biology, College of Education for Pure Science, Anbar University, Iraq; 3. Department of Biology and Microbiology, Faculty of Sciences, Mosul University, Mosul, Iraq; 4. Department of Biology, School of Bioscience and Biotechnology, Faculty of Science and Technology, The National University of Malaysia 43600 UKM, Bangi, Selangor, Malaysia.

Corresponding author: Orooba Meteab Faja, e-mail: orooba.ukm@gmail.com Co-authors: AAS: aliabd197359@uoanbar.edu.iq, KMY: khansaa.altaee@yahoo.com,

MGA: merriamghadhanfar@yahoo.com, BJM: basima.jasim@qu.edu.iq, AA: asmat@ukm.edu.my Received: 04-02-2019, Accepted: 31-05-2019, Published online: 28-07-2019

doi: 10.14202/vetworld.2019.1140-1149 How to cite this article: Faja OM, Sharad AA, Yoanis KM, Alwan MG, Mohammed BJ, Ahmad A (2019) Isolation, detection of virulence genes, antibiotic resistance genes, plasmid profile, and molecular typing among Vibrio parahaemolyticus isolated in Malaysian seawater from recreational beaches and fish, Veterinary World, 12(7): 1140-1149.

\begin{abstract}
Background and Aim: Despite the importance of the global emergence of Vibrio parahaemolyticus infections worldwide, there has been scanty information on its occurrence in Malaysian seawaters and fish. This study aimed to determine the occurrence of $V$. parahaemolyticus isolates using polymerase chain reaction targeted at toxin operon gene, thermostable direct hemolysin $(t d h)$, and $t d h$-related hemolysin genes and to determine antibiotic resistance pattern, genes, and plasmid profile of $V$. parahaemolyticus from Malaysian seawaters and fish.
\end{abstract}

Materials and Methods: Samples were collected from four recreational beaches in Malaysia (Port Klang; Bachok; Port Dickson; and Mersing). Thiosulfate-citrate-bile salts-sucrose (TCBS) agar and chromogenic Vibrio agar were used for isolation and identification. Colonies with yellow color on TCBS and green color on chromogenic vibrio (CV) agar were considered to be $V$. parahaemolyticus and they were subjected to biochemical tests. All V. parahaemolyticus isolates were further subjected to identification using seven specific gene markers.

Results: Seventy-three Vibrio isolates were recovered. Only one gene $t d h$ from seawater isolates of Vibrio has high virulence gene percentage (95.23\%). Two genes alkaline serine protease $(a s p)$ and $(t d h)$ had high percentage of virulence $(83.87 \%$ and $80.64 \%$, respectively) from fish. Comparatively, fish isolates have a higher virulence percentage compared to seawater isolates. Only gene streptomycin resistance B (strB) from seawater had $100 \%$ of the resistance genes. All isolates were multi-antibiotic resistant. Seventeen antibiotic resistance patterns were observed. The isolates had plasmids of varying sizes ranging from $2.7 \mathrm{~kb}$ to $42.4 \mathrm{~kb}$. Dendrogram based on antibiotic resistance patterns of $V$. parahaemolyticus isolates discriminated the isolates into three clusters.

Conclusion: This study demonstrated the occurrence of pathogenic, multi-antibiotic-resistant $V$. parahaemolyticus strains in Malaysian coastal waters and fish, and this could constitute potential public health risks.

Keywords: antibiotic resistance genes, plasmid profile, Vibrio parahaemolyticus, virulence genes.

\section{Introduction}

The genus Vibrio consists of aquatic microbes which normally live in coastal and estuarine water bodies [1]. The bacteria are known to be ubiquitous in these environments as they have been isolated from seawater, fish, and shellfish [2]. One of the pathogenic species of Vibrio that is commonly isolated from coastal and estuarine water bodies all over the world is Vibrio parahaemolyticus. It is a Gram-negative halophilic bacterial [3] and it is present in abundance.

Copyright: Faja, et al. Open Access. This article is distributed under the terms of the Creative Commons Attribution 4.0 International License (http://creativecommons.org/licenses/by/4.0/), which permits unrestricted use, distribution, and reproduction in any medium, provided you give appropriate credit to the original author(s) and the source, provide a link to the Creative Commons license, and indicate if changes were made. The Creative Commons Public Domain Dedication waiver (http://creativecommons.org/ publicdomain/zero/1.0/) applies to the data made available in this article, unless otherwise stated.
The distribution of $V$. parahaemolyticus in the marine and estuarine environments has been reported to vary based on the temperature of the water $[2,4]$. The consumption of foods contaminated with a high level of $V$. parahaemolyticus and/or pathogenic $V$. parahaemolyticus has been associated with gastrointestinal infections [5,6]. Concomitantly, V. parahaemolyticus infections in humans have been frequently reported in coastal areas as a result of increased consumption of seafood and direct contact with Vibrio contaminated estuarine waters [7]. Among Vibrio species of clinical importance, V. parahaemolyticus produces virulence factors that encode the thermostable direct hemolysin $(t d h)$ and/or the $t d h$-related hemolysin $(t r h)$; which have been reported to contribute to the pathogenicity of the species [8]. Resistance to antimicrobials, on the other hand, has now been acknowledged as a critical threat to public health as well as food security 
globally [9]. Most of the common antibiotics that are frequently utilized are no longer effective. The widespread use and misuse of antibiotics in aquaculture, agriculture, and livestock production have been considered to be one of the fundamental factors influencing the emergence and spread of antimicrobial resistance. Multidrug-resistant bacterial strain is another emerging challenge when a bacterial cell becomes resistant toward multiple antibiotics [10].

Despite the importance of the global emergence of $V$. parahaemolyticus infections worldwide in the coastal areas, there has been scant information on the diversity of $V$. parahaemolyticus in Malaysian coastal waters and fish. This information is readily available, could be used for better policy formulation and implementation, thereby mitigating the increasing rate of human $V$. parahaemolyticus infection visa-vise antibiotic resistance.

This study aimed to determine the presence of $V$. parahaemolyticus isolates to the species level using polymerase chain reaction (PCR) targeting the toxin operon (toxR) gene, to determine the virulence factors using PCR technique directed at $t d h$ and $t r h$ genes and to determine antibiotic resistance and plasmid profile of $V$. parahaemolyticus isolates from Malaysian coastal waters and fish.

\section{Materials and Methods}

\section{Ethical approval}

Samples were collected as per standard sample collection method. There is no need to obtain ethical approval for such type of study.

\section{Bacterial isolation and identification}

The isolation of $V$. parahaemolyticus from seawater and fish (Sea bass) was done using Sterile $500 \mathrm{~mL}$ Schott bottles for the collection of seawater [11], while sterile disposable plastic containers were used for fish collection [12]. The samples were collected from four recreational beaches of Malaysia (Port Klang, Selangor; Bachok, Kelantan; Port Dickson, Negeri Sembilan; and Mersing, Johor). Serial dilution method and spread plate technique were employed for culturing V. parahaemolyticus. Thiosulfate-citrate-bile salts-sucrose (TCBS) Agar-TCBS (Oxoid, UK) and Chromogenic Vibrio Agar CV (Titan Media, India) were used for isolation and identification of bacteria. The colonies that appeared yellow on TCBS agar and green on $\mathrm{CV}$ agar were considered as V. parahaemolyticus and they were subjected to biochemical tests following Food and Drug Administration (FDA) and Bergey's manuals [13].

\section{DNA and plasmid extraction}

For the DNA extractions, DNA was extracted from the $73 \mathrm{~V}$. parahaemolyticus isolates using DNA Purification Kit (Promega, USA), following the manufacturer's manual. The extracted genomic DNA was then stored at $-20^{\circ} \mathrm{C}$ for further studies. For plasmid extractions, $V$. parahaemolyticus was cultivated overnight in $5 \mathrm{ml}$ of Luria Bertani broth (Oxoid, UK) with an addition of $4 \%(\mathrm{w} / \mathrm{v}) \mathrm{NaC} 1$ at $35^{\circ} \mathrm{C}$, using FavorPrep ${ }^{\mathrm{TM}}$ Plasmid Extraction Mini Kit (Favorgen Biotech Corp., Taiwan) following manufacturer's instruction. The plasmid DNA products were stored at $-20^{\circ} \mathrm{C}$ for further analysis. The final products of both processes were then loaded in $1 \%(\mathrm{w} / \mathrm{v})$ agarose gel. The gel electrophoresis was run at $85 \mathrm{~V}$ for $1 \mathrm{~h}$. One $\mathrm{kb}$ Extend DNA ladder (New England Biolabs, USA) and $1 \mathrm{~kb}$ DNA ladders (Invitrogen, Belgium) were used as DNA markers. The gel was then visualized and recorded under ultraviolet (UV) light using GeneSys G: BOX EF2 (Syngene, USA) device [14].

\section{Molecular identification of $\boldsymbol{V}$. parahaemolyticus}

All $V$. parahaemolyticus isolates that were identified biochemically were then subjected to identification using specific gene markers. Briefly, DNA gyrase subunit $\mathrm{B}(g y r \mathrm{~B})$ gene with primer sequences of $g y r$ B-F 5'-CGG CGT GGG TGT TTC GGT AGT3') ( $g y r \mathrm{~B}-\mathrm{R} 5$ '-TCC GCT TCG CGC TCA TCA ATA-3' as described previously [15] was used to identify $V$. parahaemolyticus. Identification by $16 \mathrm{~s}$ rRNA gene sequencing was equally done using the following primes (27F 5'-AGA GTT TGA TCM TGG CTC AG-3') and (1492R 5' -TAC GGY TAC CTT GTT ACG ACT T -3') as previously described [16] and some of the isolates were submitted to GenBank with accession numbers as shown in Table-1.

\section{Detection of virulence genes}

A total of 73 isolates (42 recovered from seawater and 31 from fish) of $V$. parahaemolyticus were screened for the presence of virulence genes. PCR assays were applied to target the virulence determinant $t d h$ gene, trh gene, thermolabile hemolysin gene (th), tox $\mathrm{R}$ gene, outer membrane protein, and alkaline serine protease (asp) [18,19]. Details of primers used are listed in Table-2. For each primer, initial optimization experiments were conducted to ascertain optimal PCR conditions for $\mathrm{MgCl}_{2}$ and annealing temperatures and the reaction mixture of the total volume of $25 \mu \mathrm{L}$ was prepared. PCR conditions used are presented in Table-3. Reference strains ( $V$. parahaemolyticus ATCC 17802, V. parahaemolyticus ATCC 43996, and Escherichia coli ATCC 25992) were used to standardized the reaction. All reactions were conducted in a Mastercycler ${ }^{\circledR}$ thermal cycler (Eppendorf, Germany). Gel electrophoresis assay was done by mixing $10 \mu \mathrm{L}$ of the amplicon with $2 \mu \mathrm{L}$ of gel loading dye and electrophoresed in pre-stained $1.0 \%$ agarose (Sigma-Aldrich, USA) for $1 \mathrm{~h}$ at $80-90 \mathrm{~V}$ in $1 \times$ TrisAcetate Ethylenediaminetetraacetic acid (TAE) buffer (FirstBase Sdn Bhd, Malaysia). The $100 \mathrm{bp}$ and $1 \mathrm{~kb}$ DNA ladders (Invitrogen, Belgium) were used as a molecular size marker.

\section{PCR amplification of antibiotic resistance genes}

All $V$. parahaemolyticus isolates $(\mathrm{n}=73)$ were screened phenotypically for the presence of antibiotic resistance genes using 14 different antibiotics 
Table-1: The sequences similarity of the 16S rRNA gene of $V$. parahaemolyticus strains isolated from Malaysia with those previously deposited in NCBI (GenBank) database from other related studies.

\begin{tabular}{|c|c|c|c|}
\hline Isolate code & GenBank accession number & Isolate names & Identification ( $\%$ identity) \\
\hline VPCW3 & MF278586.1 & $\begin{array}{l}\text { V. parahaemolyticus strain } \\
\text { ukmVp1 }\end{array}$ & 91 \\
\hline VPDW1 & МH071288.1 & $\begin{array}{l}\text { V. parahaemolyticus strain } \\
\text { ukmVp2 }\end{array}$ & 99 \\
\hline VPDS4 & MF347992.1 & $\begin{array}{l}\text { V. parahaemolyticus strain } \\
\text { ukmVp3 }\end{array}$ & 93 \\
\hline VPIS1 & MH021958.1 & $\begin{array}{l}\text { V. parahaemolyticus strain } \\
\text { ukmVp4 }\end{array}$ & 99 \\
\hline VPKS3 & МH071289.1 & $\begin{array}{l}\text { V. parahaemolyticus strain } \\
\text { ukmVp5 }\end{array}$ & 97 \\
\hline VPLW1 & МH071290.1 & $\begin{array}{l}\text { V. parahaemolyticus strain } \\
\text { ukmVp6 }\end{array}$ & 95 \\
\hline
\end{tabular}

V. parahaemolyticus $=$ Vibrio parahaemolyticus

Table-2: Primer used to detect virulence genes in this study.

\begin{tabular}{|c|c|c|}
\hline $\begin{array}{l}\text { Gene } \\
\text { name }\end{array}$ & $\begin{array}{l}\text { Primer } \\
\text { name }\end{array}$ & Primer sequence $\left(5^{\prime}\right.$ to $\left.3^{\prime}\right)$ \\
\hline \multirow[t]{2}{*}{$t d h$} & $t d h-\mathrm{F}$ & CCATTCTGGCAAAGTTATT \\
\hline & $t d h-\mathrm{R}$ & TTCATATGCTTCTACATTAAC \\
\hline \multirow[t]{2}{*}{ trh } & trh-F & TTGGCTTCGATATTTTCAGTATCT \\
\hline & trh-R & CATAACAAACATATGCCCATTTCCG \\
\hline \multirow[t]{2}{*}{$t / h$} & $t / h-F$ & AGCGGATTATGCAGAAGCAC \\
\hline & $t / h-\mathrm{R}$ & ATCTCAAGCACTTTCGCACG \\
\hline \multirow[t]{2}{*}{ toxR } & toxR-F & GATTAGGAAGCAACGAAAG \\
\hline & toxR-R & GCAATCACTTCCACTGGTAAC \\
\hline \multirow[t]{2}{*}{ ompK } & ompK-F & GGCGGTCGCTCTGGTATT \\
\hline & ompK-R & TTGCCATCGTAAGTGCTGTA \\
\hline \multirow[t]{2}{*}{ asp } & asp-F & CGAAGCGGGCTGGGGTTA \\
\hline & asp-R & ACATGCGGTGTGGCCATAGAGG \\
\hline \multirow[t]{2}{*}{ COIA } & colA-F & CGAGTACAGTCACTTGAAAGCC \\
\hline & COlA-R & CACAACAGAACTCGCGTTACC \\
\hline
\end{tabular}

$t d h=$ Thermostable direct hemolysin, $t r h=T D H$-related hemolysin, $t / h=$ Thermolabile hemolysin, tox $R=$ Toxin operon, ompK: Outer membrane protein, asp=Alkaline serine protease, $c o / A=$ Collagenase

(ampicillin $[10 \mu \mathrm{g}]$, amoxicillin [10 $\mu \mathrm{g}]$, chloramphenicol [30 $\mu \mathrm{g}]$, ciprofloxacin [10 $\mu \mathrm{g}]$, gentamycin [10 $\mu \mathrm{g}]$, erythromycin [15 $\mu \mathrm{g}]$, nitrofurantoin [200 $\mu \mathrm{g}]$, kanamycin $[30 \mu \mathrm{g}]$, cephalothin [30 $\mu \mathrm{g}]$, nalidixic acid [30 $\mu \mathrm{g}$ ], penicillin $[10 \mu \mathrm{g}]$, carbenicillin [100 $\mu \mathrm{g}]$, streptomycin [25 $\mu \mathrm{g}]$, and tetracycline [30 $\mu \mathrm{g}]$ ) (Oxoid, UK) through disc diffusion method [20] and followed by genotype screening using PCR technique to detect the carriage of genes coding for resistance to antibiotics. The following resistant genes; streptomycin resistance $(\operatorname{str} B)$, $\beta$-lactamase resistance (blaPl), chloramphenicol resistance $(f l o R)$, tetracycline resistance (tet $A)$, erythromycin resistance $(\mathrm{erm} B)$, quinolone resistance protein $(q n r A)$, and aminoglycosides resistance (aac(3)-IIa) were employed in this investigation for detection of genes responsible for resistance as previously described $[21,22]$. The primers' list and PCR reaction conditions are listed in Tables-2 and 4, respectively $[18,19]$. All reactions were conducted in a Mastercycler ${ }^{\mathbb{B}}$ thermal cycler (Eppendorf, Germany). Positive and negative controls were included for each set of amplification. A $100 \mathrm{bp}$ and $1 \mathrm{~kb}$ DNA ladder (Invitrogen, Belgium) were used as molecular size markers.

\section{Molecular typing of $V$. parahaemolyticus by randomly} amplified polymorphic DNA (RAPD)-PCR

To assess the utility of RAPD-PCR in the subtyping of $V$. parahaemolyticus recovered during the study, all isolates were subjected to RAPD-PCR. The Gen1 5'-AGGATACGTG-3' primer [23] was used for the RAPD-PCR reactions. Vibrio vulnificus ATCC 27562 was used as a reference and negative controls were performed by adding $1 \mu \mathrm{L}$ of sterile ultrapure deionized water [24]. PCR amplifications were performed in $0.2 \mathrm{~mL}$ and the total volume of the reaction mixture was $50 \mu \mathrm{L}$ consisting of $25 \mu \mathrm{L} 10 \times$ PCR master mix (EconoTaq ${ }^{\circledR}$ Plus Green 2X Master Mix, Lucigen, $\mathrm{UK}), 0.5 \mu \mathrm{L}$ of primer and template DNA $1.0 \mu \mathrm{L}$ and then the volume adjusted to the final volume by addition of nuclease-free water (NFW). PCR conditions adopted involving initial denaturation at $95^{\circ} \mathrm{C}$ for $5 \mathrm{~min}$ followed by 45 cycles of denaturation at $94^{\circ} \mathrm{C}$ for $1 \mathrm{~min}$, annealing for $1 \mathrm{~min}$ at $35^{\circ} \mathrm{C}$, and polymerization at $72^{\circ} \mathrm{C}$ for $2 \mathrm{~min}$. Final elongation was at $72^{\circ} \mathrm{C}$ for $7 \min$ [25].

Molecular typing of $\boldsymbol{V}$. parahaemolyticus by enterobacterial repetitive intergenic consensus (ERIC)-PCR

The ERIC-PCR assay was performed on all $V$. parahaemolyticus isolates that were recovered during the study. The PCR technique was carried out in $0.2 \mathrm{ml}$ microcentrifuge tubes, with a $50 \mu \mathrm{L}$ reaction mixture consisting of $25 \mu \mathrm{L}$ of $2 \mathrm{X}$ DreamTaq Green PCR Master Mix (Thermo Scientific, USA), $1 \mu \mathrm{L}$ of $100 \mu \mathrm{M}$ of each ERIC primers as described previously by Versalovic et al. [24]; ERIC-1 (5'- CAC TTA GGG GTC CTC GAA TGT A -3') and ERIC-2 (5'- AAG TAA GTG ACT GGG GTG AGC G -3') [25], $1 \mu \mathrm{L}$ of approximately $100 \mathrm{ng}$ DNA template. This was followed by adjusting the volume to $50 \mu \mathrm{L}$ by adding NFW. Both positive and negative, DNA controls were included in each reaction. The cycling conditions were as follows: Pre-denaturation at $95^{\circ} \mathrm{C}$ for $7 \mathrm{~min}$, denaturation at $90^{\circ} \mathrm{C}$ for $30 \mathrm{~s}$, annealing at $58^{\circ} \mathrm{C}$ for $1 \mathrm{~min}$, and extension at $65^{\circ} \mathrm{C}$ for $8 \mathrm{~min}$, and with a final extension at $68^{\circ} \mathrm{C}$ for $16 \mathrm{~min}$ at the end of 30 cycles.

\section{RAPD and ERIC-PCR analysis}

A $10 \mu \mathrm{L}$ volume of each PCR product was mixed with $2 \mu \mathrm{L}$ of loading dye and subjected to a $1 \% \mathrm{TAE}$ 
Table-3: Antibiotic resistance patterns and plasmid profiling of Vibrio parahaemolyticus.

\begin{tabular}{|c|c|c|c|}
\hline Antibiotics & Isolate codes & Pattern & Plasmid Size (kb) \\
\hline $\begin{array}{l}\text { AM, AX, C, CN, E, F, K, KF, NA, } \\
P, P Y, S, T E\end{array}$ & VPDW1, VPKW1, VPLW1 & A & $\begin{array}{c}3.8,7.3,10.2,15 \\
42.4\end{array}$ \\
\hline $\begin{array}{l}\text { AM, AX, C, CIP, E, F, K, KF, P, } \\
P Y, S, T E\end{array}$ & VPKW2, VPLW2 & $\mathrm{B}$ & $3.8,7.3,13.5,42.4$ \\
\hline $\begin{array}{l}\text { AM, AX, C, E, F, K, NA, P, PY, } \\
S, T E\end{array}$ & VPCW3. VPEW2, VPFW4, VPHW4, VPIW1, VPJW3 & C & $2.7,3.8,10.2$ \\
\hline$A M, A X, E, F, K, P, P Y, S, T E$ & VPLW3 & $\mathrm{D}$ & $5.6,8.2$ \\
\hline $\mathrm{AM}, \mathrm{AX}, \mathrm{CN}, \mathrm{P}, \mathrm{PY}, \mathrm{S}, \mathrm{TE}$ & $\begin{array}{l}\text { VPAW1, VPBW2, VPCW1, VPCW8, VPEW1, } \\
\text { VPGW1, VPHW1, VPHW2, VPIW4, VPIW9, } \\
\text { VPJW5, VPKW3, VPKW5 }\end{array}$ & $\mathrm{E}$ & $2.7,3.8,42.4$ \\
\hline$A M, A X, F, P, P Y, S, T E$ & VPEW3, VPKW4 & $\mathrm{F}$ & 32 \\
\hline$A M, N A, P, P Y, S$ & VPCW4, VPGW5 & G & ND \\
\hline $\mathrm{AM}, \mathrm{PY}, \mathrm{S}$ & $\begin{array}{l}\text { VPAW4, VPBW4, VPCW2, VPCW6, VPCW7, } \\
\text { VPHW10, VPHW3, VPHW6, VPIW6, VPJW1, } \\
\text { VPJW2, VPJW4, VPJW6 }\end{array}$ & $\mathrm{H}$ & ND \\
\hline $\begin{array}{l}\text { AM, AX, C, CIP, CN, E, F, K, NA, } \\
P, P Y, S, T E\end{array}$ & VPDS4, VPIS1, VPKS3 & $\mathrm{I}$ & $2.7,13.5,15,32$ \\
\hline $\begin{array}{l}\text { AM, AX, C, E, KF, NA, P, PY, S, } \\
\text { TE }\end{array}$ & VPKS1, VPLS2 & 了 & $3.8,5.6,8.2$ \\
\hline$A M, A X, C N, E, K, N A, P, P Y$ & VPCS2, VPES1 & $\mathrm{K}$ & ND \\
\hline AM, AX, K, P, PY, S, TE & VPKS5, VPLS3 & $\mathrm{L}$ & $10.2,42.4$ \\
\hline $\mathrm{AM}, \mathrm{CN}, \mathrm{K}, \mathrm{KF}, \mathrm{S}$, TE & VPAS4, VPBS1, VPCS1, VPDS1, VPKS6, VPLS4 & M & $6,13.5$ \\
\hline$A M, A X, K, P, P Y, S$ & VPAS1, VPBS2, VPDS2, VPLS1 & $\mathrm{N}$ & ND \\
\hline$A M, A X, N A, P, P Y$ & VPBS3, VPDS5, VPHS3, VPJS1 & $\mathrm{O}$ & ND \\
\hline$A M, A X, P, P Y$ & VPAS5, VPCS3, VPHS1, VPJS3 & $\mathrm{P}$ & ND \\
\hline$A M, P, P Y$ & VPAS3, VPAS6, VPCS4, VPIS2 & Q & ND \\
\hline
\end{tabular}

$\mathrm{ND}=$ Not detected, $\mathrm{AM}=$ Ampicillin, $\mathrm{AX}=$ Amoxicillin, $\mathrm{C}=$ Chloramphenicol, $\mathrm{CN}=$ Gentamycin, $\mathrm{E}=$ Erythromycin,

$\mathrm{F}=$ Nitrofurantoin, $\mathrm{K}=$ Kanamycin, $\mathrm{KF}=$ Cephalothin, $\mathrm{NA}=$ Nalidixic acid, $\mathrm{P}=$ Penicillin, $\mathrm{PY}=$ Carbenicillin, $\mathrm{S}=$ Streptomycin, $\mathrm{TE}=$ Tetracycline, $\mathrm{CIP}=$ Ciprofloxacin, $\mathrm{E}=$ Erythromycin, $\mathrm{F}=$ Nitrofurantoin, $\mathrm{K}=$ Kanamycin

Table-4: Polymerase chain reaction conditions of detection of virulence genes.

\begin{tabular}{|c|c|c|c|c|c|c|c|c|}
\hline Gene & Size (bp) & Primer Conc. & $\operatorname{dnTP}(\mu \mathrm{M})$ & Taq poly. (units) & $\mathrm{MgCl}_{2}(\mathrm{mM})$ & Buffer & Anneal Temp $\left({ }^{\circ} \mathrm{C}\right)$ & References \\
\hline$t d h$ & 534 & 0.5 & 200 & 0.04 & 2.0 & $1 x$ & 48 & [17] \\
\hline trh & 500 & 0.5 & 200 & 0.04 & 2.0 & $1 x$ & 52 & [17] \\
\hline$t / h$ & 150 & 0.5 & 200 & 0.04 & 2.0 & $1 x$ & 54 & {$[17]$} \\
\hline toxR & 658 & 0.5 & 200 & 0.04 & 2.0 & $1 x$ & 54 & {$[17]$} \\
\hline ompK & 319 & 0.5 & 200 & 0.04 & 2.0 & $1 x$ & 57 & [18] \\
\hline asp & 750 & 0.5 & 200 & 0.04 & 2.0 & $1 x$ & 53 & [18] \\
\hline COIA & 737 & 0.5 & 200 & 0.04 & 2.0 & $1 x$ & 58 & [19] \\
\hline
\end{tabular}

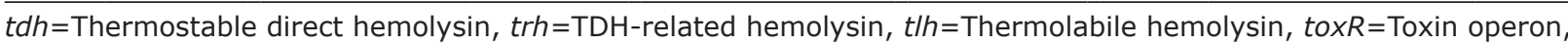
ompK=Outer membrane protein, as $p=$ Alkaline serine protease, $\operatorname{col} A=$ Collagenase

buffer electrophoresis system. In each run, a molecular weight marker 100 bp PCR ladder (Invitrogen) was included. Following the completion of electrophoresis, the gel was photographed using a UV transilluminator and the relatedness of the bacterial isolates was estimated by ERIC-PCR and RAPD-PCR according to the photographic image of the gel using ImageJ. The data obtained then were clustered using average linkage (unweighted group pair method with arithmetic averages, [UPGMA]) using PHYLIP (version 3.697) (University of Washington, USA) application and the analysis was performed in dendrogram form.

\section{Results}

Percentage of virulence genes of $\boldsymbol{V}$. parahaemolyticus The percentages of virulence genes of V. parahaemolyticus from seawater, fish, and all isolates that were recovered during this study are depicted in Figure-1. Seven genes were evaluated, and our analysis revealed that only one gene from seawater isolates has a high virulence gene percentage, and this was gene $t d h$, which had $95.23 \%$ virulence (Table-5). The gene with the least virulence percentage from seawater isolate was found to be gene $\operatorname{trh}(9.52 \%)$. Genes from isolates of fish, on the other hand, revealed that two of the genes have a high percentage of virulence and these were asp and $t d h$ genes which had $83.87 \%$ and $80.64 \%$ of virulence, respectively, while two other genes (tlh and toxR) had $64.51 \%$ virulence each. The gene with the least virulence percentage from the fish isolate was trh, which had $16.12 \%$ virulence. However, only one gene from all isolate had a high percentage of virulence and this was $t d h$ with the virulence of $89.04 \%$, and one other gene (asp) had $60.27 \%$ of virulence. The gene with the least virulence percent from all isolates was trh gene with the virulence of $12.32 \%$. Comparatively, isolates from fish had genes with higher virulence percentage compared to seawater isolates. 
Antibiotic resistance patterns and plasmid profile of V. parahaemolyticus

The rate of seven resistance genes of $V$. parahaemolyticus from seawater, fish and all isolates were determined in this study, and the findings

Table-5: Percentage of virulence genes of Vibrio parahaemolyticus.

\begin{tabular}{lccc}
\hline Gene & $\begin{array}{c}\text { Seawater } \\
\mathbf{n = 4 2}(\mathbf{\%})\end{array}$ & $\begin{array}{c}\text { Fish } \\
\mathbf{n = 3 1}(\boldsymbol{\%})\end{array}$ & $\begin{array}{c}\text { All isolates } \\
\mathbf{n = 7 3}(\mathbf{\%})\end{array}$ \\
\hline asp & $18(42.85)$ & $26(83.87)$ & $44(60.27)$ \\
colA & $12(28.57)$ & $10(32.25)$ & $22(30.13)$ \\
ompk & $18(42.85)$ & $11(35.48)$ & $29(39.72)$ \\
tdh & $40(95.23)$ & $25(80.64)$ & $65(89.04)$ \\
tlh & $12(28.57)$ & $20(64.51)$ & $32(43.83)$ \\
trh & $4(9.52)$ & $5(16.12)$ & $9(12.32)$ \\
toxR & $12(28.57)$ & $20(64.51)$ & $32(43.83)$ \\
\hline
\end{tabular}

$a s p=$ Alkaline serine protease, $c o l A=$ Collagenase, ompK=Outer membrane protein, $t d h=$ Thermostable direct hemolysin gene, $t / h=$ Thermolabile hemolysin, trh $=\mathrm{TDH}$-related hemolysin, tox $R=$ Toxin operon are depicted in Figures-2 and 3 and Table-6. Analysis of the findings revealed that only one gene $(s t r B)$ from seawater isolates had $100 \%$ of the resistance gene followed by tetA with $64.28 \%$ of the resistance gene. The rest of the genes from this group had low rates of resistance genes with the least being from $\operatorname{aac}(3)$ lla, which had $7.14 \%$ of the resistance gene. No gene from fish isolates possesses $100 \%$ of resistance gene seeing that the highest rate of resistance was found in blaP1 with $80.64 \%$ of the resistance gene. The rest of the genes under this group had moderate to low rates of resistance genes and the gene with the lowest rate of resistance from this group was floR with $16.12 \%$ of resistance. Similarly, no gene from all isolates had $100 \%$ of the resistance gene as the highest rate of resistance gene was $\operatorname{str} B$, which had $80.82 \%$ of the resistance gene. Most of the genes in this group had moderate-to-low rates of resistance, with the least rate of resistance with aac(3)-lla with $16.43 \%$ of

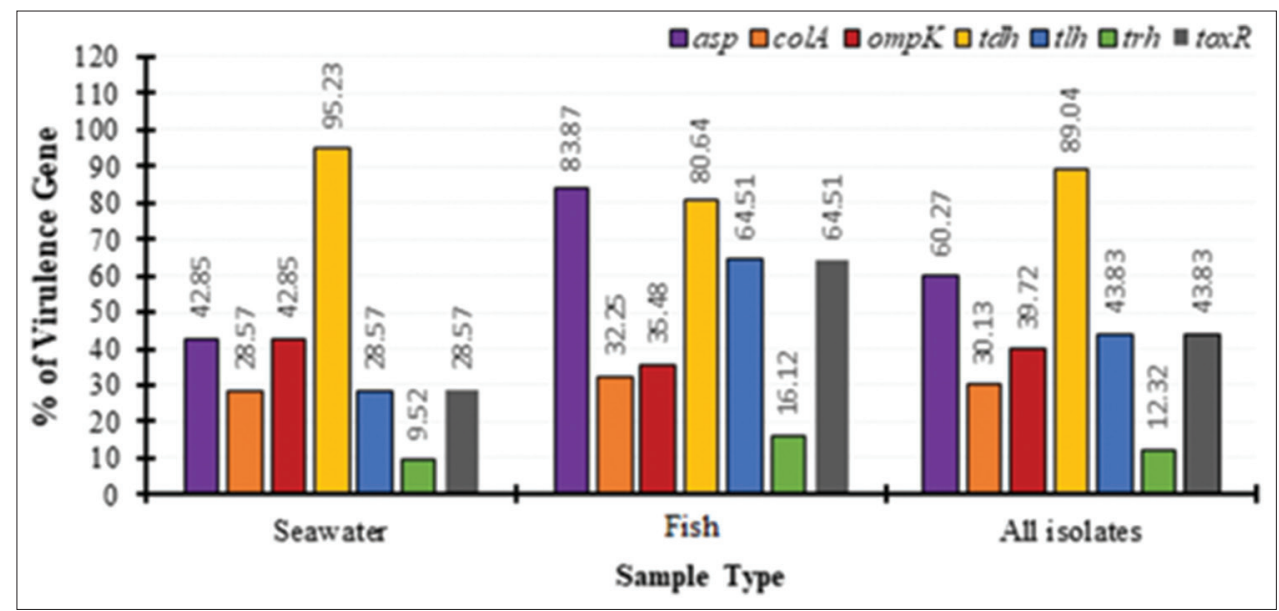

Figure-1: Percentage of virulence genes of Vibrio parahaemolyticus from seawater isolates, isolates from fish and all isolates.

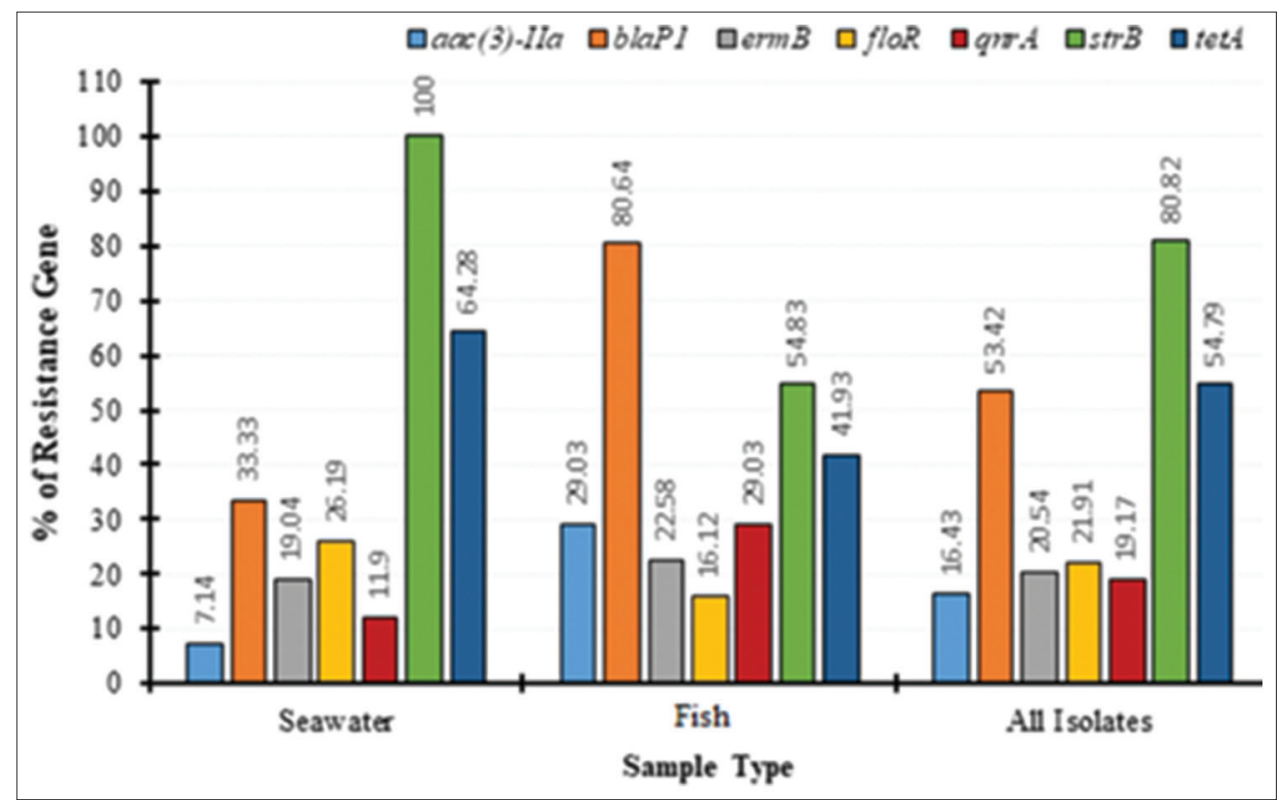

Figure-2: Percentages of seven resistance genes of Vibrio parahaemolyticus from seawater isolates, isolates from fish and all isolates. 
Table-6: Antibiotic resistance gene patterns of Vibrio parahaemolyticus.

\begin{tabular}{|c|c|c|}
\hline Resistance gene profile & Isolate codes & Pattern \\
\hline $\begin{array}{l}\text { aac (3)-IIa, blaP1, floR, qnrA, strB, } \\
\text { tetA }\end{array}$ & VPDW1, VPKW1, VPLW1 & A \\
\hline ermB, floR, qnrA, strB, tet $A$ & VPKW2, VPLW2 & $\mathrm{B}$ \\
\hline blaP1, ermB, floR, strB, tet $A$ & VPCW3, VPEW2, VPFW4, VPHW4, VPIW1, VPJW3 & $\mathrm{C}$ \\
\hline blaP1, strB, tet $A$ & VPLW3 & $\mathrm{D}$ \\
\hline strB, tetA & $\begin{array}{l}\text { VPAW1, VPBW2, VPCW1, VPCW8, VPEW1, VPGW1, } \\
\text { VPHW1, VPHW2, VPIW4, VPIW9, VPJW5, VPKW3, } \\
\text { VPKW5 }\end{array}$ & $E$ \\
\hline blaP1, strB, tet $A$ & VPEW3, VPKW4 & $\mathrm{F}$ \\
\hline blaP1, strB & VPCW4, VPGW5 & G \\
\hline strB & $\begin{array}{l}\text { VPAW4, VPBW4, VPCW2, VPCW6, VPCW7, VPHW10, } \\
\text { VPHW3, VPHW6, VPIW6, VPJW1, VPJW2, VPJW4, } \\
\text { VPJW6 }\end{array}$ & $\mathrm{H}$ \\
\hline $\begin{array}{l}\text { aac (3)-IIa, blaP1, ermB, floR, qnrA, } \\
\text { strB, tetA }\end{array}$ & VPDS4, VPIS1, VPKS3 & I \\
\hline ermB, floR, qnrA, strB, tet $A$ & VPKS1, VPLS2 & 了 \\
\hline aac (3)-IIa, blaP1, ermB & VPCS2, VPES1 & $\mathrm{K}$ \\
\hline blaP1, strB, tet $A$ & VPKS5, VPLS3 & $\mathrm{L}$ \\
\hline blaP1, strB, tet $A$ & VPAS4, VPBS1, VPCS1, VPDS1, VPKS6, VPLS4 & M \\
\hline aаc (3)-IIa, strB & VPAS1, VPBS2, VPDS2, VPLS1 & $\mathrm{N}$ \\
\hline blaP1, qnrA & VPBS3, VPDS5, VPHS3, VPJS1 & $\mathrm{O}$ \\
\hline blaP1 & VPAS5, VPCS3, VPHS1, VPJS3 & $P$ \\
\hline blaP1 & VPAS3, VPAS6, VPCS4, VPIS2 & Q \\
\hline
\end{tabular}

str $B=$ Streptomycin resistance, $b l a P 1=\beta$-lactamase resistance, floR $=$ Chloramphenicol resistance, tet $A=$ Tetracycline

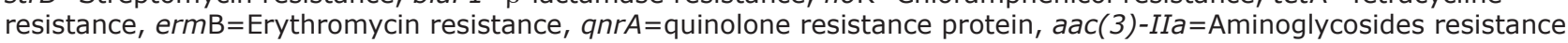

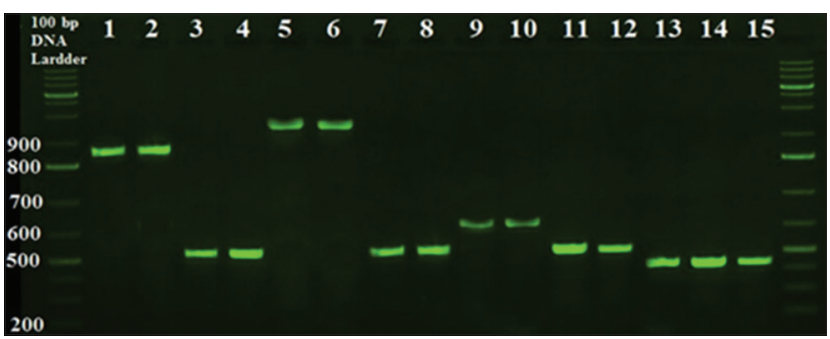

Figure-3: Detection of antibiotic resistance genes in Vibrio parahaemolyticus isolates by polymerase chain reaction technique, electrophoresed on $1.5 \%(\mathrm{w} / \mathrm{v})$ agarose gel. Lanes 1, 2: $\beta$-lactamase resistance gene in VPEW3 and VPGW5. Lanes 3, 4: streptomycin resistance gene in VPAW1 and VPBW2. Lanes 5, 6: tetracycline Resistance gene in VPKS1 and VPLS2. Lanes 7, 8: chloramphenicol resistance gene in VPDS4 and VPIS1. Lanes 9, 10: erythromycin resistance gene in VPCW3 and VPEW2. Lanes 11, 12: quinolone resistance protein gene in VPDW1 andVPKW1. Lanes 13, 14, 15: aminoglycosides resistance gene in VPLW1, VPDW1, and VPKW1.

resistance. There was no regular pattern in the rate of resistance from all the three groups.

\section{Percentages of antibiotic resistance genes of v. parahaemolyticus}

Based on the analysis of the results of $V$. parahaemolyticus isolated from this study, all the isolates were multi-antibiotic-resistant as all the isolates were resistant to at least three different antibiotics, with isolates VPDW1, VPKW1, VPLW1, VPDS4, VPIS1, and VPKS3 being resistant to 13 of the different antibiotics tested (Table-3). Seventeen different antibiotic resistance patterns were observed in this study. The isolates have plasmids of varying sizes ranging from $2.7 \mathrm{~kb}$ to $42.4 \mathrm{~kb}$ even though the majority of the isolates were plasmidless. The dendrogram based on antibiotic resistance patterns of the $V$. parahaemolyticus isolates discriminated the isolates into three clusters (Figure-4).

\section{Molecular fingerprinting of $V$. parahaemolyticus by RAPD-PCR and ERIC-PCR typing}

The dendrogram of typeable $V$. parahaemolyticus isolates produced from RAPD-PCR and ERIC-PCR analysis using average linkage UPGMA is shown in Figures-4 and 5, respectively. The RAPD-PCR analysis discriminated typeable $V$. parahaemolyticus isolate into three clusters and one single isolate. On the other hand, the ERIC-PCR analysis discriminated typeable $V$. parahaemolyticus isolates into 12 clusters and six single isolates.

\section{Discussion}

The pathogenicity of $V$. parahaemolyticus has been reported to be largely influenced by two common virulence genes among others and these are the $t d h$ and $t r h$ [26]. In this study, seven genes were evaluated and our analysis revealed that only one gene from seawater isolates of $V$. parahaemolyticus had a high virulence gene percentage and this was gene $t d h$ which had $95.23 \%$ tdh gene. The gene with the least virulence percentage from seawater isolate was found to be gene trh $(9.52 \%)$. Two genes from fish isolate have a high percentage of virulence and these were asp and $t d h$ genes which had $83.87 \%$ and $80.64 \%$ of virulence, respectively, while two other genes ( $t$ lh and tox $\mathrm{R}$ ) have $64.51 \%$ virulence each. These percentages of virulence genes obtained in this study are relatively high compared to those reported in an earlier study [26], where $16.2 \%$ was reported. In a related study [27], it was reported that Vibrio isolates possess 


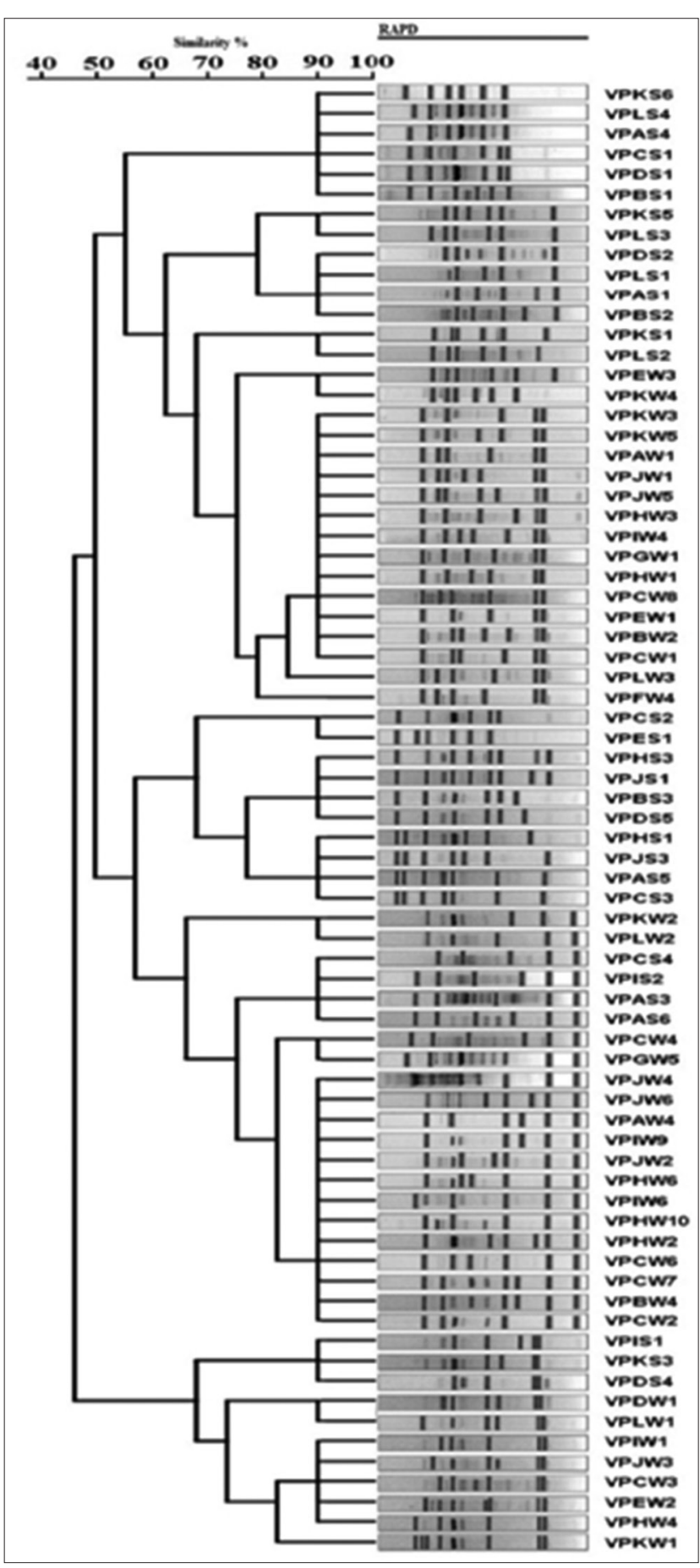

Figure-4: Dendrogram of typeable Vibrio parahaemolyticus isolates produced from randomly amplified polymorphic DNA analysis using average linkage unweighted group pair method with arithmetic averages.

$100 \%$ tox $R$ virulence gene and this is relatively high compared to the $64.51 \%$ tox $R$ reported in this study. The gene with the least virulence percentage from the fish isolate was trh, which had $16.12 \%$ virulence, which has been similarly reported by Tan et al. [26]. However, only one gene from all isolate had a high percentage of virulence and this was $t d h$ with the virulence of $89.04 \%$ and one other gene (asp) had $60.27 \%$ of virulence. The findings of $t d h$ with $89.04 \%$ of virulence gene corroborate with the findings of Oliva et al. [28], who reported $68.2 \%$ of virulence gene of

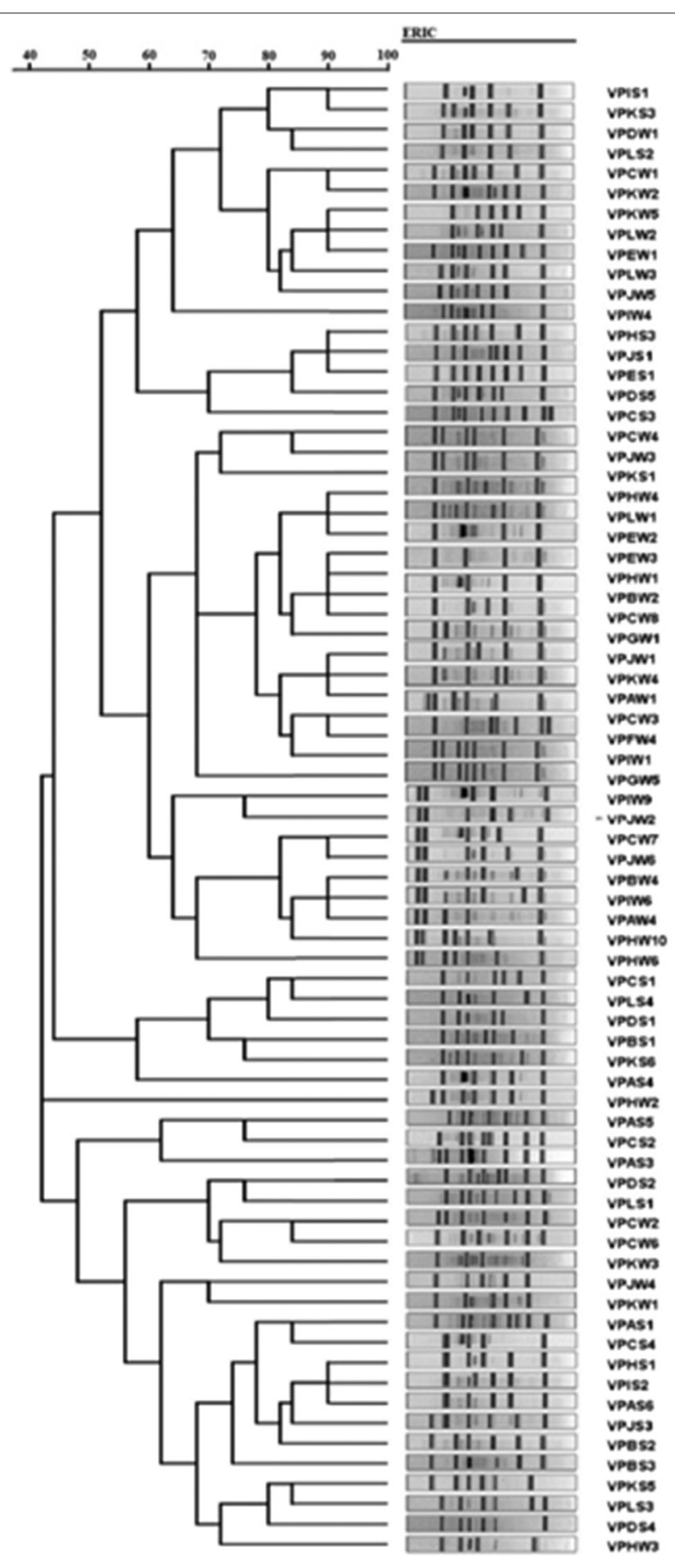

Figure-5: Dendrogram of typeable Vibrio parahaemolyticus isolates produced from enterobacterial repetitive intergenic consensus analysis using average linkage unweighted group pair method with arithmetic averages.

Vibrio isolates to be $t d h$ gene. The gene with the least virulence percent from all isolate was trh gene with the virulence of $12.32 \%$. Comparatively, isolates from fish had genes with higher virulence percentage compared to seawater isolates.

Antibiotic susceptibility of Vibrio species has been documented in several studies $[9,26]$. In this study, analysis of the findings revealed that only one gene $(s t r B)$ from seawater isolates had $100 \%$ of the resistance gene followed by tet $A$ with $64.28 \%$ of the 
resistance gene. This was relatively very high compared to the rate reported in an earlier study [26], where Vibrio isolates were reported to have only $13.33 \%$ of the resistance gene. The rest of the genes from this group had low rates of resistance genes with the least being from aac(3)-lla, which had 7.14\% of the resistance gene. These findings corroborate with those reported by Tan et al. [26] who reported $12.5 \%$ of aac(3)-lla from Vibrio isolated from seawater. No gene from fish isolates had $100 \%$ of resistance gene seeing that the highest rate of resistance was found in blaPl with $80.64 \%$ of the resistance gene. In an earlier study [26], the percentage of blaP1 in Vibrio isolates from seawater was reported to be $65 \%$, which is comparatively lower than the $80.64 \%$ found in this study. The rest of the genes under this group had moderate to low rates of resistance genes and the gene with the lowest rate of resistance from this group was floR with $16.12 \%$ of resistance. Similarly, no gene from all isolates had $100 \%$ of resistance gene as the highest rate of resistance gene was $\operatorname{str} B$ which had $80.82 \%$ of resistance gene which was relatively low compared to those reported by Tan et al. [26]. In another related study [29], the rate of $s t r B$ resistance gene was reported to be $22.2 \%$. Most of the genes in this group have moderate-to-low rates of resistance, with the least rate of resistance seen aac(3)-lla with $16.43 \%$ of resistance. There was no regular pattern in the rate of resistance from all the three groups.

Conventionally, Vibrio has been known to be greatly susceptible to nearly all antimicrobials. Nevertheless, recently, resistance to antimicrobials has emerged and evolved in numerous bacterial genera as a result of the excessive utilization of antimicrobial agents in human, agriculture as well as aquaculture systems [30]. In this study, all the $V$. parahaemolyticus isolated were resistant to at least three different antibiotics, with isolates VPDW1, VPKW1, VPLW1, VPDS4, VPIS1, and VPKS3 being resistant to 13 of the different antibiotics tested. This corroborates with the findings reported in other related studies [21,31], who reported variations in the pattern of antibiotic resistance of $V$. parahaemolyticus. Seventeen different antibiotic resistance patterns were observed in this study. These results of ours were inconsonant with the findings of You et al. [32], who reported 20 different antibiotic resistance patterns in Vibrio isolates. The isolates had plasmids of varying sizes ranging from $2.7 \mathrm{~kb}$ to $42.4 \mathrm{~kb}$ even though the majority of the isolates were plasmidless. You et al. [32] had also reported plasmid sizes ranging from $2.2 \mathrm{~kb}$ to $24.8 \mathrm{~kb}$ in Vibrio strains isolated in their study, as similarly found in this study. The dendrogram based on antibiotic resistance patterns of the V.parahaemolyticus isolates discriminated the isolates into three clusters. In an earlier related study [33], $V$. parahaemolyticus was similarly discriminated into four clusters by RAPD-PCR and ERIC-PCR analysis.
Molecular techniques for Vibrio identification as well as subtyping have been developed, and these include DNA microarray technologies and PCR-based techniques that target species-specific determinants. PCR-based molecular-typing studies have been performed with ERIC-PCR and RAPD analysis [34]. The RAPD-PCR analysis in this study discriminated typeable $V$. parahaemolyticus isolate into three clusters and one single isolate. These findings of ours corroborate with the findings reported in an earlier study [35], who documented that Vibrio isolates were discriminated into two clusters by RAPD-PCR analysis. The ERICPCR analysis, on the other hand, discriminated typeable $V$. parahaemolyticus isolates into 12 clusters and six single isolates. These findings corroborate with the findings of Bhowmick et al. [36], who reported that $V$. parahaemolyticus isolates were discriminated into 2,4 , and 10 clusters at $20 \%, 35 \%$, and $45 \%$ similarity using RAPD-PCR analysis. The authors [36] similarly reported that ERIC-PCR discriminated the $V$. parahaemolyticus isolates into 3, 4, and 7 clusters at $10 \%$, $25 \%$, and $45 \%$ similarity. In another related study [33], V. parahaemolyticus was discriminated into four clusters by RAPD-PCR and ERIC-PCR analysis, which comparatively agree with the findings of this study. Yet in another study [37], V. parahaemolyticus was discriminated into four clusters by RAPD-PCR analysis as similarly observed in this study.

\section{Conclusion}

In this study, Vibrio parahaemolyticus was isolated from four different seawaters and fish collected from Malaysian beaches. These isolates were found to have virulence genes as well as antibiotic resistance genes. They were also found to be multi-antibiotic-resistant. The isolation of $V$. parahaemolyticus species with virulence genes and antibiotic resistance genes in Malaysia beaches and fish is an interesting finding, and the information generated in this study could be used to guard the public on the possible public health risk in these recreational beaches as well as consumption of infected fish.

\section{Authors' Contributions}

OMF and AA designed the study protocol. OMF, AAS, KMY, MGA, and BJM were involved in sample collection. OMF wrote the paper while OMF, AAS, and AA were involved in drafting the manuscript. All authors revised, read, and approved the final manuscript.

\section{Acknowledgments}

The authors would like to appreciate The National University of Malaysia for supporting this study with the grant number; 04-01-02-SF014, Ministry of Science, Technology, and Innovation (MOSTI) of Malaysia and UKM (GUP BTK 07-75-198).

\section{Competing Interests}

The authors declare that they have no competing interests. 


\section{Publisher's Note}

Veterinary World remains neutral with regard to jurisdictional claims in published institutional affiliation.

\section{References}

1. Ghenem, L., Elhadi, N., Alzahrani, F. and Nishibuchi, M. (2017) Vibrio parahaemolyticus: A review on distribution, pathogenesis, virulence determinants and epidemiology. Saudi J. Med. Med. Sci., 5(2): 93-103.

2. Alonzo, K.H.F., Cadiz, R.E., Traifalgar, R.F.M. and Corre, V.L. Jr. (2017) Immune responses and susceptibility to Vibrio parahaemolyticus colonization of juvenile Penaeus vannamei at increased water temperature. Aquac. Aquar. Conserv. Legis. (Bioflux), 10(5): 1238-1247.

3. Alagappan, K.M., Deivasigamani, B., Somasundaram, S.T. and Kumaran, S. (2010) Occurrence of Vibrio parahaemolyticus and Its specific phages from shrimp ponds in east coast of India. Curr. Microbiol., 61(4): 235-240.

4. Zorriehzahra, M.J. and Banaederakhshan, R. (2015) Early mortality syndrome (EMS) as new emerging threat in shrimp industry. Adv. Anim. Vet. Sci., 3(2S): 64-72.

5. Scallan, E., Hoekstra, R.M., Angulo, F.J., Tauxe, R.V., Widdowson, M.A., Roy, S.L., Jones, J.L. and Griffin, P.M. (2011) Foodborne illness acquired in the United States major pathogens. Emerg. Infect. Dis., 17(1): 7-15.

6. Joshi, J., Srisala, J., Sakaew, W., Prachumwat, A., Sritunyalucksana, K., Flegel, T.W. and Thitamadee, S. (2014) Identification of bacterial agent (s) for acute hepatopancreatic necrosis syndrome, a new emerging shrimp disease. Suranaree J. Sci. Technol., 21(4): 315-320.

7. Ralston, E.P., Kite-Powell, H. and Beet, A. (2011) An estimate of the cost of acute health effects from food-and waterborne marine pathogens and toxins in the USA. J. Water Health, 9(4): 680-694.

8. Drake, S.L., DePaola, A. and Jaykus, L.A. (2007) An overview of Vibrio vulnificus and Vibrio parahaemolyticus. Compr. Rev. Food Sci. Food Saf., 6(4): 120-144.

9. Food and Agriculture Organization. (2016) Drivers, Dynamics and Epidemiology of Antimicrobial Resistance in Animal Production. Available from: http://www.fao. org/3/a-i6209e.pdf. Accessed on 20-07-2019.

10. Van Hoek, A. H. A., Mevius, D., Guerra, B., Mullany, P., Roberts, A.P. and Aarts, H.J.M. (2011) Acquired antibiotic resistance genes: An overview. Front. Microbiol., 2(1: 203.

11. Facchinelli, A., Sacchi, E. and Mallen, L. (2001) Multivariate statistical and gis-based approach to identify heavy metal sources in soils. Environ. Pollut., 114(3): 313-324.

12. Elmanama, A.A., Fahd, M.I., Afifi, S., Abdallah, S. and Bahr, S. (2005) Microbiological beach sand quality in Gaza Strip in comparison to seawater quality. Environ. Res., 99(1): 1-10.

13. Jayasinghe, C., Ahmed, S. and Kariyawasam, M. (2010) The isolation and identification of Vibrio species in marine shrimps of Sri Lanka. J. Sci. Food Agric., 1(1): 36-44.

14. Devi, R., Surendran, P. and Chakraborty, K. (2005) Antibiotic resistance and plasmid profiling of Vibrio parahaemolyticus isolated from shrimp farms along the southwest coast of India. World J. Microbiol. Biotechnol., 25(11): 2005-2012.

15. Luan, X.Y., Chen, J.X., Zhang, X.H., Jia, J.T., Sun, F.R. and Li, Y. (2007) Comparison of different primers for rapid detection of Vibrio parahaemolyticus using the polymerase chain reaction. Lett. Appl. Microbiol., 44(3): 242-247.

16. Rolph, H., Lennon, A., Riggio, M., Saunders, W., Mackenzie, D., Coldero, L. and Bagg, J. (2001) Molecular identification of microorganisms from endodontic infections. J. Clin. Microbiol., 39(9): 3282-3289.

17. Xie, Z.Y., Hu, C.Q., Chen, C., Zhang, L.P. and Ren, C.H. (2005) Investigation of seven Vibrio virulence genes among Vibrio alginolyticus and Vibrio parahaemolyticus strains from the coastal mariculture systems in Guangdong, China, Lett Appl Microbiol., 41(2): 202-207.

18. Cai, S., Wu, Z., Jian, J. and Lu, Y. (2007) Cloning and expression of the gene encoding an extracellular alkaline serine protease from Vibrio alginolyticus strain hy9901, the causative agent of vibriosis in Lutjanus erythopterus (Bloch). J. Fish Dis., 30(8): 493-500.

19. Najwaa, M.N., Danielb, A.M.D., Amin, K.M. and Effendya, A. (2015) Detection of virulence genes in Vibrio alginolyticus isolated from green mussel, Perna viridis. $J$. Teknol., 77(25): 19-23.

20. Wayne, P.A. (2006) Clinical and laboratory standards institute methods for dilution antimicrobial susceptibility tests for bacteria that grow aerobically. In: Performance Standards for Antimicrobial Disk Susceptibility Tests. $9^{\text {th }}$ ed. CLSI, Wayne, PA.

21. Raissy, M., Moumeni, M., Ansari, M. and Rahimi, E. (2012) Antibiotic resistance pattern of some Vibrio strains isolated from seafood. Iran. J. Fish. Sci., 11(3): 618-626.

22. García-Aljaro, C., Riera-Heredia, J. and Blanch, A.R. (2014) Antimicrobial resistance and presence of the SXT mobile element in Vibrio spp. isolated from aquaculture facilities. New Microbiol., 37(3): 339-346.

23. Radu, S., Elhadi, N., Hassan, Z., Rusul, G., Lihan, S., Fifadara, N. and Purwati, E. (1998) Characterization of Vibrio vulnificus isolated from cockles (Anadara granosa): Antimicrobial resistance, plasmid profiles and random amplification of polymorphic DNA analysis. FEMS Microbiol. Lett., 165(1): 139-143.

24. Sahilah, A.M., Audrey, L.Y.Y., Ong, S.L., Wan Sakeenah, W.N., Saiyyah, S., Norrakiah, A.S. and Azuhairi, A.A. (2010) DNA profiling among egg and beef meat isolates of Escherichia coli by enterobacterial repetitive intergenic consensus-PCR (ERIC-PCR) and random amplified polymorphic DNA-PCR (RAPD-PCR). Int. Food Res. J., 17(4): 853-866.

25. Versalovic, J., Koeuth, T. and Lupski, R. (1991) Distribution of repetitive DNA sequences in eubacteria and application to fingerprinting of bacterial genomes. Nucleic Acids Res., 19(24): 6823-6831.

26. Tan, C.W., Malcolm, T.T., Kuan, C.H., Thung, T.Y., Chang, W.S., Loo, Y.Y. and Rukayadi, Y. (2017) Prevalence and antimicrobial susceptibility of Vibrio parahaemolyticus isolated from short mackerels (Rastrelliger brachysoma) in Malaysia. Front. Microbiol., 8(13: 1087.

27. Igbinosa, E.O. and Obuekwe, I.S. (2014) Evaluation of antibiotic resistant gene in abattoir environment. J. Appl. Sci. Environ. Manage., 18(2): 165-170.

28. Oliva, M.S.,Bronzato, G.F., de Castro Soares, L., Pereira,I.A., Pribul, B.R., de Souza, M.A.S. and de Souza, M.M.S. (2016) Detection of virulence and antibiotic resistance genes in environmental strains of Vibrio spp. from mussels along the coast of Rio de Janeiro State, Brazil. Afr. J. Microbiol. Res., 10(24): 906-913.

29. Li, J., Yie, J., Foo, R.W., Ling, J.M., Xu, H. and Woo, N.Y. (1999) Antibiotic resistance and plasmid profiles of Vibrio isolates from cultured silver sea bream, Sparus sarba. Marine Pollut. Bull., 39(1-12): 245-249.

30. Mazel, D. and Davies, J. (1999) Antibiotic resistance in microbes. Cell. Mol. Life Sci., 56(9-10): 742-754.

31. Letchumanan, V., Yin, W.F., Lee, L.H. and Chan, K.G. (2015) Prevalence and antimicrobial susceptibility of Vibrio parahaemolyticus isolated from retail shrimps in Malaysia. Front. Microbiol., 6(1): 33.

32. You, K.G., Bong, C.W. and Lee, C.W. (2016) Antibiotic resistance and plasmid profiling of Vibrio spp. in tropical waters of Peninsular Malaysia. Environ. Monit. Assess., 188(3): 171

33. Zulkifli, Y., Alitheen, N.B., Son, R., Raha, A.R., Samuel, L., Yeap, S.K. and Nishibuchi, M. (2009) Random amplified polymorphic DNA-PCR and ERIC PCR analysis on Vibrio parahaemolyticus isolated from cockles in Padang, 
Indonesia. Int. Food Res. J., 16(2): 141-150.

34. Høi, L., Dalsgaard, A., Larsen, J.L., Warner, J.M. and Oliver, J.D. (1997) Comparison of ribotyping and randomly amplified polymorphic DNA PCR for characterization of Vibrio vulnificus. Appl. Environ. Microbiol., 63(5): 1674-1678.

35. Gutacker, M., Conza, N., Benagli, C., Pedroli, A., Bernasconi, M.V., Permin, L. and Piffaretti, J.C. (2003) Population genetics of Vibrio vulnificus: Identification of two divisions and a distinct eel-pathogenic clone. Appl.
Environ. Microbiol., 69(6): 3203-3212.

36. Bhowmick, P.P., Khushiramani, R., Raghunath, P., Karunasagar, I. and Karunasagar, I. (2008) Molecular typing of Vibrio parahaemolyticus isolated from seafood harvested along the south-west coast of India. Lett. Appl. Microbiol., 46(2): 198-204.

37. Sudheesh, P.S., Jie, K. and Xu, H.S. (2002) Random amplified polymorphic DNA-PCR typing of Vibrio parahaemolyticus and $V$. alginolyticus isolated from cultured shrimps. Aquaculture, 207(1-2): 11-17.

$* * * * * * * *$ 